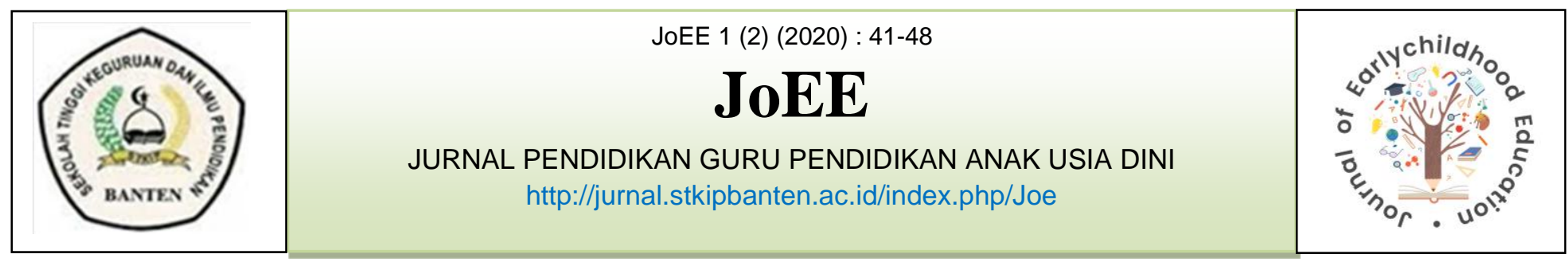

\title{
PENGGUNAAN PERMAINAN KARTU HURUF HIJAIYAH UNTUK MENINGKATKAN KEMAMPUAN KOGNITIF ANAK USIA DINI DALAM MEMBACA IQRA
}

\author{
Nia Kurniasih \\ kurniasihnia@gmail.com \\ Pendidikan Guru Pendidikan Anak Usia Dini \\ Sekolah Tinggi Keguruan dan Ilmu Pendidikan Banten
}

\begin{abstract}
Abstrak
Pendidikan merupakan suatu proses kegiatan yang ditujukan untuk mempengaruhi manusia. Manusia yang mampu mengadakan intraksi dengan lingkungan sekitarnya. Proses tersebut dilaksanakan secara sistematis dan terencana yang akan di kembangkan secara terus menerus. Tujuan penelitian ini adalah untuk mengetahui Kemampuan membaca iqra pada anak usia dini sebelum menggunakan permainan kartu huruf hijaiyah dan untuk mengetahui kemampuan membaca iqra anak usia dini sesudah menggunakan permainan kartu huruf hijaiyah. Peneltian ini adalah penelitian kepustakaan ( Library Research ), Pengumpulan data peneliti menggunakan paper dan journal ilmiah, tesis dan disertasi, skripsi, dan dokumentasi. Hasil penelitian yang telah dilakukan memperoleh hasil persentase yang menunjukan adanya peningkatan hasil belajar siswa, terlihat dalam kode data artikel A1 skor pretes menunjukan data dari $40 \%$ ketuntasan klasikal menjadi 53\% sehingga peningkatannya $13 \%$, kode data A2 menunjukan dari $22,08 \%$ menjadi 79,58 \% dengan peningkatan mencapai 57,5 \%, kode data A3 dari $25 \%$ menjadi $66,7 \%$. dengan peningkatan mencapai $41,7 \%$. Adapun rata-rata hasil pretes sebelum menggunakam model pembelajaran permainan kartu huruf hijaiyah yaitu $29,02 \%$ dan sesudah menggunakan model permainan kartu huruf hijaiyah meningkat menjadi $66,42 \%$ dengan rata-rata peningkatan $27,4 \%$.
\end{abstract}

Kata Kunci : Permainan Kartu Huruf Hijaiyah, Kemampuan Kognitif

\section{PENDAHULUAN}

Setiap manusia berhak memperoleh pendidikan,baik itu TK, RA, PAUD maupun pendidikan yang lebih lanjut. Pendidikan merupakan suatu proses kegiatan yang ditujukan untuk mempengaruhi manusia.Manusia yang mampu mengadakakan intraksi dengan lingkungan sekitarnya. Proses tersebut dilaksanakan secara sistematis dan terencana yang akan di kembangkan secara terus menerus.
Berdasarkan peraturan Menteri Pendidikan Kebudayaan Nomor 137 tahun 2014 tentang standar pendidikan anak usia dini, Perkembangan kemampuan membaca dapat dibagi atas tahap perkembangan, (1) Tahap kesadaran terhadap tulisan, (2) Tahap Membaca Gambar, (3) Tahap pengenalan bacaan, (4) Tahap membaca lancar (Martini, Perkembangan dan Pengembangan anak Usia Dini, 2016)

Sedangkan menurut UU Sisdiknas No.20 tahun 2003 bab1 pasal 1 ayat 14 mengatakan bahwa Pendidikan Anak Usia 
Dini adalah suatu upaya pembinaan yang ditunjukkan kepada anak sejak lahir sampai dengan usia enam tahun yang dilakukan melalui pemberian rangsangan pendidikan untuk membantu pertumbuhan dan perkembangan jasmani dan rohani agar anak memiki kesiapan dalam memasuki pendidikan lebih lanjut. (kumpulan pedoman pembelajaran taman kanak-kanak, 2010)

Khadijah mengungkapkan

bahwa Anak Usia Dini adalah anak yang baru dilahirkan sampai usia enam tahun. Usia ini merupakan usia yang sangat tmenentukan dalam pembentukan karakter dan kepribadian anak. Usia dini merupakan usia dimana anak mengalami pertumbuhan dan perkembangan yang sangat pesat. Usia dini di sebut sebagai usia emas (golden age ) (Khadijah, 2012)

$$
\text { Hasil observasi peneliti }
$$

menunjukkan bahwa pengembangan nmembaca iqra belum berkembang disaat anak disuruh membaca sendiri, ada anak yang kurang dalam kemampuan mengingat huruf hijaiyah, ada anak yang belum bias membedakan diantara beberapa huruf hijaiyah seperti huruf $ت$ dan $b$, jdan $\dot{ }$. Selain itu guru hanya menggunakan media papan tulis sebagai tempat untuk menuliskan dan menjelaskan huruf hijaiyah tersebut serta hanya menggunakan buku menulis huruf hijaiyah untuk anak usia dini sebagai buku tugas siswa. (Mutia Nanda Herlina, 2018)

Berdasarkan penemuan di atas peneliti memberikan suatu tindakan dengan adanya kegiatan permainan diharapkan kemampuan dalam pemahaman huruf-huruf hijaiyah anak usia dini akan dapat berkembang secara baik dan anak bisa lebih antusias dalam belajar.

Berdasarkan latar belakang masalah diatas ,dapat dirumuskan masalahnya sebagai berikut:

1.Bagaimana pengembangan permainan kartu huruf hijaiyah dalam meningkatkan kemampuan kognitif AUD ?
1.Bagaimana kemampuan kognitif AUD dengan menggunakan permainan kartu huruf hijaiyah?

Adapun tujuan dari penelitian ini adalah sebagai berikut :

1. Kemampuan membaca pada anak usia dini sebelum menggunakan permainan kartu huruf hijaiyah

2. Kemampuan membaca anak usia dini sesudah menggunakan permainan kartu huruf hijaiyah

Bermain bagi anak usia dini sangat penting, sebab melalui bermainlah anak dapat mengalami proses pembelajaran. Selain itu karakteristik anak usia dini yaitu suka bermain (Fadillah, 2017)

Peran bermain bagi perkembangan anak dapat dilihat pada uraian berikut (Fadillah, 2017)

1) Bermain mengembangkan motoric. Piaget berpendapat bahwa anak terlahir dengan kemampuan reflex kemudian menggabungkan 2 atau lebih gerak reflex, dan pada akhirnya dia mampu mengontrol gerakannya

2) Bermain mengembangkan kognitif. Masih menurut piaget bahwa anak mengkontruksikan pengetahuan dengan berinteraksi dengan objek yang ada disekitarnya

3) Bermain mengembangkan kemampuan afektif. Kemampuan afektif adalah kemampuan yang berhubungan dengan sikap seseorang. Kemampuan ini dapat dikembangkan dan dilatih melalui kegiatan bermain

4) Bermain mengembangkan kemampuan bahasa. Pada saat bermain anak menggunakan bahasa, baik untuk berkomunikasi dengan temannya atau hanya sekedar menayatakan pemikirannya

5) Bermain mengembangkan kemampuan sosial. Pada saat bermain secara langsung anak berinteraksi dengan anak yang lain. Interaksi tersebut 
mengajarkan anak bagaimana merespon, memberi dan menerima.

Fatul Mujib dan Nailur Menyatakan Permainan merupakan suatu aktifitas yang bertujuan memperoleh keterampilan tertentu dengan cara menggembirakan seseorang tertentu dengan cara menggembirakan seseorang dengan orang lainnya, barang (mainan) atau hewan yang dapat terjadi dalam konteks tertentu, baik pembelajaran (learning) maupun rekreatif dalam menemukan identitas, mempelajari sebab akibat, mengembangkan hubungan,memperaktikan kemampuan, serta memengaruhi segenap faktor dan aspek kehidupan. (Purnama, 2011)

Rasyid mengatakan Mengenal huruf adalah hal penting bagi anak usia dini yang didengardari lingkungannya baik huruflatin, huruf Arab dan lainnya. Berbagai huruf yang dikenal anak menumbuhkan kemampuan untuk memilih dan memilah berbagai jenis huruf. Melatih anak untuk mengenal huruf dan mengucapkannya mesti harus diulangulang. Dalam mengenal huruf sangat penting untuk anak, karena anak akan mengenali satu persatu huruf dan membacanya menjadi sebuah kata. untuk mengenali huruf-huruf anak dapat dilatih untuk mengucapkannya huruf-huruf tersebut berulang-ulang. (Mutia Nanda Herlina, 2018)

Kartu huruf adalah penggunaan sejumlah kartu sebagai alat bantu untuk belajar membaca dengan cara melihat dan mengingat bentuk huruf dan gambar yang disertai tulisan dari makna gambar pada kartu. Kartu huruf sebagai alat peraga yang mudah diingat oleh anak dengan adanya tulisan dan gambar pada kartu yang dapat membuat anak terasa lebih menyenangkan saat belajar dengan menggunakan media. (Mutia Nanda Herlina, 2018)

Sirojudin mengatakan Huruf hijaiyah merupakan Alfabet Arab yang disebut dengan huruf al hija (iyah) dan huruf al tahajji artinya huruf ejaan.Ahli gramatika Arab menamakannya huruf al 'arabiyah atau huruf al lugah al'arabiyah maksudnya huruf bahasa arab atau huruf yang bertanda baca atau bertitik (huruf al mu'jam) baik dalam bentuk terpisah-pisah yang belum dipahami sehingga menjadi sebuah rangkaian kata ataupun karena beberapa bagian darinya atau seluruhnya ditambahi tanda baca.Huruf hijaiyah tersebut disusun atas dua bentuk yaitu mufrad (tunggal) dan muzdawij (berangkai). Sirojuddin (dalam Indah widiyas tuti dkk:2014:2) (Indah widiyas Tuti Ningrum, 2014)

Kartu huruf hijaiyyah yang digunakan dalam penelitian ini adalah alat peraga atau media yang digunakan untuk proses belajar mengajar dalam rangka mempermudah atau memperjelas penyampaian materi pelajaran. Kartu huruf hijaiyyah yang berfungsi untuk mempermudah anak dalam pemahaman suatu konsep sehingga prestasi pembelajaran lebih menyenangkan dan lebih efektif.,media atau alat peraga adalah sesuatu yang dapat di inderakan yang berfungsi sebagai perantara (Sarana atau alat untuk proses komunikasi / proses belajar mengajar. (Kartini, 2011)

Perkembangan kognitif adalah proses terjadi secara internal di dalam pusat susunan syaraf pada waktu manusia sedang berfikir. Kemampuan kognitif ini perkembangan fisik dan syarat-syarat yang berada di pusat syaraf. Salah satu teori yang berpengaruh dalam menjelaskan perkembangan kognitif (Martini, Perkembangan dan Pengembangan anak Anak Usia Dini, 2016)

Perkembangan kognitif mengacu pada perkembangan anak dalam berpikir dan memberikan kemampuan untuk memberikan alasan. Malkus, Feldman, dan Gardner dalam Carton dan Allen menggambarkan perkembangan kognitif sebagai kapasitas untuk bertumbuh untuk menyampaikan dan menghargai maksud dalam penggunaan beberapa system symbol yang secara kebetulan ditonjolkan dalam suatu bentuk pengaturan.System symbol ini meliputi kata-kata, gambaran, isyarat, dan angka-angka. 
Menurut Piaget Perkembangan kognitif bertujuan untuk memperoleh strukturstruktur psikologis yang diperlukan supaya manusia mampu berfikir secara logis dan mampu mengadakan penalaran secara abstrak mengenai masalah-masalah actual dan hipotesis. Piaget memandang anak sebagai organisme aktif yang berkembang dengan impuls-impuls internal dan pola-pola perkembangan tertentu (Sumanto, 2014)

Menurut Montessori Membaca merupakan kecakapan fundamental anak paling penting yang akan selalu dipelajari. Membaca suatu proses untuk memahami makna suatu tulisan. Proses yang dialami dalam membaca adalah berupa penyajian kembali dan penafsiran suatu kegiatan dimulai dari mengenali huruf, kata, ungkapan, frase, kalimat, dan wacana serta menghubungkannya dengan bunyi dan maknanya. Bahkan lebih jauh dari itu dalam kegiatan membaca, pembaca menghubungkannya dengan maksud penulis berdasarkan pengalamannya. Sedangkan menurut Sudarso bahwaa membaca artinya aktivitas kompleks dengan mengarahkan sebagian besar tindakan yang terpisah-pisah. (Fahmi, 2015)

Membaca suatu proses untuk memahami makna suatu tulisan. Proses yang dialami dalam membaca adalah berupa penyajian kembali dan penafsiran suatu kegiatan dimulai dari mengenali huruf, kata, ungkapan, frase, kalimat, dan wacana serta menghubungkannya dengan bunyi dan maknanya. Bahkan lebih jauh dari itu dalam kegiatan membaca, pembaca menghubungkannya dengan maksud penulis berdasarkan pengalamannya.Sedangkan menurut Sudarso bahwaa membaca artinya aktivitas kompleks dengan mengarahkan sebagian besar tindakan yang terpisah-pisah.

(Fahmi, 2015)

\section{TABEL DAN GAMBAR}

Dari tabel tersebut diketahui bahwa dari ke-3 artikel ,2 jurnal dan 1 skripsi tersebut dalam penelitian ini terkait permainan kartu huruf hijaiyah untuk meningkatkan kemampuan kognitip maka yang menjadi bahan kajian yaitu sebagai berikut:

Tabel 1. Daftar artikel Jurnal dan skripsi Permainan kartu huruf hijaiyah untuk Meningkatkan kemampuan kognitif adalah:

\begin{tabular}{|c|c|l|l|l|l|l|}
\hline No. & $\begin{array}{c}\text { Kode } \\
\text { Data }\end{array}$ & $\begin{array}{c}\text { Variabel } \\
\text { Terikat }\end{array}$ & $\begin{array}{l}\text { Metode } \\
\text { Penelitian }\end{array}$ & Sampel & Hasil & Keterangan \\
\hline 1 & A1 & $\begin{array}{l}\text { Meningkatka } \\
\text { n Membaca }\end{array}$ & $\begin{array}{l}\text { Penelitian } \\
\text { Tindakan } \\
\text { Kelas } \\
\text { (PTK) }\end{array}$ & $\begin{array}{l}15 \\
\text { siswa }\end{array}$ & $\begin{array}{l}\text { skor pretes menunjukan } \\
\text { data dari 40\% menjadi } \\
53 \% \text { sehingga } \\
\text { peningkatannya 13\%. }\end{array}$ & $\begin{array}{l}\text { Terjadi } \\
\text { Peningkatan }\end{array}$ \\
\hline 2 & A2 & $\begin{array}{l}\text { Kemampuan } \\
\text { mengenal } \\
\text { huruf } \\
\text { hijaiyah }\end{array}$ & $\begin{array}{l}\text { Kuantitatif } \\
\text { pre- } \\
\text { experiment } \\
\text { al }\end{array}$ & $\begin{array}{l}24 \\
\text { siswa }\end{array}$ & $\begin{array}{l}\text { skor pretes menunjukan } \\
\text { data dari 22,08\% } \\
\text { menjadi 79,58\% } \\
\text { sehingga } \\
\text { peningkatannya 57,5\%. }\end{array}$ & $\begin{array}{l}\text { Terjadi } \\
\text { Peningkatan }\end{array}$ \\
\hline 3 & A3 & $\begin{array}{l}\text { Kemampuan } \\
\text { Membaca } \\
\text { Iqra }\end{array}$ & $\begin{array}{l}\text { Penelitian } \\
\text { Tindakan } \\
\text { Kelas } \\
\text { (PTK) }\end{array}$ & $\begin{array}{l}12 \\
\text { siswa } \\
\text { data dari 25\% menjadi } \\
\text { 66,7\% sehingga } \\
\text { peningkatannya 41,7\%. }\end{array}$ & $\begin{array}{l}\text { Terjadi } \\
\text { Peningkatan }\end{array}$ \\
\hline
\end{tabular}


Keterangan :

A1: Putri Sarah

A2 : Rina Amellia

A3 : Sapri

\section{METODE PENELITIAN}

Studi literature dilakukan dengan cara mempelajari dan mengkaji bukubuku yang ada hubungannya dengan masalah yang diteliti untuk memperoleh bahan-bahan atau sumber-sumber tentang masalah yang akan diteliti. Teknik ini selain digunakan untuk melengkapi serta memperkuat landasan peneliti sebelum melakukan penelitiaan juga untuk melengkapi hasil penelitian yang peneliti lakukan

Teknik Pengumpulan Data Dalam metode deskriptif instrument utama yang digunakan adalah dengan menggunakan, observasi, studi literatur, dan studi dokumentasi (Diantama, 2018)

Jenis penelitian ini adalah penelitan kepustakaan (library research), yaitu serangkaian penelitian yang berkenaan dengan metode pengumpulan data pustaka, atau penelitian yang obyek penelitiannya digali melalui beragam informasi kepustakaan (buku, ensiklopedi, jurnal ilmiah, koran, majalah,dan dokumen

Tekhnik yang digunakan untuk pengumpulan data dalam penelitian ini adalah tehnik observasi. Observasi merupakan cara menghimpun bahan-bahan keterangan yang dilakukan dengan mengadakan pengamatan secara sistematis terhadap fenomena-fenomena yang dijadikan objek pengamatan. Observasi dalam penelitian ini untuk mengamati apakah melalui media kartu huruf dapat mengembangkan kemampuan membaca huruf hijaiyah pada diri anak

\section{HASIL}

Berdasarkan hasil penelitian bahwa penggunaan permainan kartu huruf hijaiyah dapat meningkatkan kemampuan

kognitif anak usia dini dalam membaca iqra.

Hasil penelitian diatas dapat dilihat bahwa setiap penelitian yang telah dilakukan memperoleh hasil persentase yang menunjukan adanya peningkatan kognitif anak dalam membaca iqra terlihat dalam kode data Kode data A1 menunjukan data dari $40 \%$ menjadi $53 \%$ sehingga peningkatannya $13 \%$. Kode data A2 menunjukan data dari $22,08 \%$ menjadi $79,58 \%$ sehingga peningkatannya $57,5 \%$.

Kode data A3 menunjukan data dari $25 \%$ menjadi $66,7 \%$ sehingga peningkatannya $41,7 \%$.

Adapun Rata-rata hasil pencapaian dari ketiga judul yang dianalisis sebelum menggunakam media pembelajaran kartu huruf hijaiyah yaitu $29,02 \%$ dan sesudah menggunakan kartu huruf hijaiyah meningkat menjadi $66,42 \%$ dengan ratarata peningkatan $27,4 \%$. Dari hasil penelitain yang dilakukan peneliti-peneliti sebelumnya bahwa penggunaan permainan kartu huruf hijaiyah dapat meningkatkan kemampuan kognitif anak usia dini dalam membaca iqra.

\section{PEMBAHASAN}

Pada dasarnya manusia lahir dengan kodratnya memiliki rasa ingin tau (curiosity) atas realitas yang ada. Hal ini disebabkan karena manusia memiliki cipta (kebenaran), rasa (keindahan) dan karsa (kebaikan) yang mendorong manusia berpikir dan berpengetahuan. (Fatmawati, 2013)

Merencanakan pembelajaran harus dipersiapkan dengan matang. Guru harus memiliki pengetahuan situasi umum yang akan dihadapi, misalnya saja, tempat, situasi, dan lain-lain. Persiapan terhadap murid-murid dalam mempersiapkan pembelajaran guru juga harus mempersiapkan murid-murid, dan guru 
harus memiliki gambaran murid-muridnya. (Mursid, 2018)

Pembelajaran adalah suatu kombinasi yang tersusun meliputi unsurunsur manusiawi, material, fasilitas, perlengkapan, dan prosedur yang saling mempengaruhi mencapai tujuan pembelajaran. Manusia terlibat dalam sistem pengajaran terdiri dari siswa, guru, dan tenaga lainnnya, misalnya laboratorium. Material, meliputi bukubuku, papan tulis, dan kapur, fotograpi, slide,dan film, audio dan video tape. Fasilitas dan perlengkapan terdiri dari ruang kelas, perlengkapan audio visual, juga komputer. (Mursid, 2018)

Proses perkembangan mental bersifat universal dalam tahapan yang umumnya sama, tetapi dengan berbagi cara ditemukan adanya perbedaan penampilan kognitif pada tiap kelompok manusia. Sistem persekolahan dan keadaan sosial ekonomi mempengaruhi terjadinya perbedaan pada perkembangan anak, demikian pula dengan budaya, sistem nilai, dan harapan dalam masyarakat masingmasing. (Hartinah, 2010)

Hasil temuan yang diperoleh melalui media kartu huruf, antara lain:

1. Melalui media kartu huruf, anak memperoleh pengalaman belajar yang baik dan menyenangkan dalam belajar membaca tingkat dasar.

2. Melalui media huruf dapat menyajikan pesan-pesan pendek pada setiap kartu yang disajikan seperti: tulisan huruf hijaiyah yang ada didalam kartu memudahkan anak untuk mengingat pada bentuk-bentuk huruf hijaiyah. Hal ini dapat dilihat dari peningkatan persentase pada indikator mengenal huruf huruf hijaiyah, menyebut rangkaian huruf, dan membaca 'iqra/qiroati dan memahami aturan dalam suatu kegiatan.

3. Melalui media kartu huruf suasana dalam kelas tidak merasa tegang dan tertekan dan melalui media kartu huruf dapat membangkitkan rasa senang dan semangat anak dalam belajar.

Dengan demikian berdasarkan teori diatas dan hasil penelitian yang telah dilakukan terbukti bahwa melalui media kartu huruf hijaiyah dapat meningkatkan kemampuan kognitif anak usia dini dalam membaca iqra

\section{Simpulan}

Berdasarkan hasil analisis temuan dalam penelitian yang sudah dilakukan peneliti, dapat disimpulkan bahwa:

1. Berdasarkan hasil analisis penelitian permainan kartu huruf hijaiyah dapat meningkatkan kognitif siswa, terlihat dalam kode data artikel A1 skor pretes menunjukan data dari $40 \%$ ketuntasan klasikal menjadi 53\% sehingga peningkatannya $13 \%$, kode data A2 menunjukan dari 22,08 \%menjadi $79,58 \%$ dengan peningkatan mencapai $57,5 \%$, kode data A3 dari $25 \%$ menjadi $66,7 \%$, dengan peningkatan mencapai $41,7 \%$.

2. Adapun rata-rata hasil pretes sebelum menggunakam model pembelajaran permainan kartu huruf hijaiyah yaitu $29,02 \%$ dan sesudah menggunakan media permainan kartu huruf hijaiyah meningkat menjadi $66,42 \%$ dengan rata-rata peningkatan $27,4 \%$.

3. Dari hasil penelitian yang dilakukan peneliti-peneliti sebelumnya bahwa permainan kartu huruf hijaiyah dapat meningkatkan kognitif siswa pada anak usia dini, karena dengan menggunakan media permainan kartu huruf hijaiyah anak sangat senang dan bahagia serta meningkatkan kognitif dalam 
membaca dan mengingat huruf hijaiyah.

\section{Saran}

Berdasarkan kesimpulan diatas, maka peneliti mengajukan beberapa saran sebagai berikut:

1. Bagi guru, disarankan agar menggunakan media pembelajaran setiap pembelajaran yang akan disampaikan, khususnya dalam mengajarkan anak membaca huruf hijaiyah dengan menggunakan media kartu huruf, agar anak lebih tertarik dalam mengikuti pembelajaran.

2. Bagi pihak sekolah, disarankan lebih memperhatikan kemampuan membaca didalam kelas, caranya dengan menyediakan media atau alat peraga. Karena dengan media anak lebih cepat memahami maksud dari penyampaian guru dan anak usia dini pada umumnya cara berfikir anak di masa pra sekolah masih bersifat yang kongkrit benda-benda yang langsung dilihatnya.

3. Bagi Peneliti selanjutnya yang ingin mengadakan penelitian lebih lanjut terhadap cara meningkatkan kemampuan membaca huruf hijaiyah dengan menggunakan media kartu huruf dan disarankan untuk lebih dalam lagi meneliti materi ini, karena masih banyak hal menarik yang dapat diperoleh dengan menggunakan media pembelajaran yang lebih menarik lagi sehingga memperoleh hasil yang lebih maksimal nantinya.

\section{DAFTAR PUSTAKA}

Diantama, s. (2018). metode penelitian pendidikan. Jakarta: pustaka Rahmat.

Fadillah. (2017). Bermain dan Permaian Anak Usia Dini . Jakarta: Kencana.

Fahmi. (2015). Permasalahan anak usia dini . jakarta: untirta pers.

Fatmawati, E. (2013). mata baru penelitian kepustakaan. yogyakarta: Seagung Seto.

Hartinah, S. (2010). pengembangan peserta didik. Bandung: Reflika Aditama.

Indah widiyas Tuti Ningrum, U. A. (2014). Peningkatan Pemahaman huruf Hijaiyah melalui permainan kartu huruf.

Kartini. (2011). Peningkatan kemampuan anak mengenal huruf melalui metode bermain kartu kata. Bandung: remaja rosdakarya.

Khadijah. (2012). konsep dasar pendidikan prasekolah. Bandung: citapustaka media perintis.

kumpulan pedoman pembelajaran taman kanak-kanak. (2010). Jakarta: Dikjenkemendiknas.

Martini. (2016). Perkembangan dan pengembangan anak. Jakarta: Gramedia.

Mursid. (2018). Belajar dan Pengembangan PAUD. Bandung: Remaja Rosdakarya. 
Mutia Nanda Herlina, A. F. (2018).

Peningkatan mengenal huruf

hijaiyah melalui media kartu huruf.

Purnama, S. (2011). Pengembangan alat

Permainan Edukatif anak usia dini.

Bandung: Remaja rosdakarya.

Sumanto. (2014). Psikologi

Perkembangan. Yogyakarta:

Center of academic Publishing

Service. 